\title{
Studies directed toward the exploitation of vicinal diols in the synthesis of $(+)$-nebivolol intermediates
}

\author{
Runjun Devi and Sajal Kumar Das ${ }^{*}$
}

\author{
Letter \\ Address: \\ Department of Chemical Sciences, Tezpur University, Napaam, \\ Tezpur, Assam-784028, India \\ Email: \\ Sajal Kumar Das* - sajalkdas@gmail.com \\ ${ }^{*}$ Corresponding author \\ Keywords: \\ dihydroxylation; epoxide-ring opening; heterocycles; nebivolol; \\ syn-epoxide
}

\author{
Beilstein J. Org. Chem. 2017, 13, 571-578. \\ doi:10.3762/bjoc. 13.56 \\ Received: 04 January 2017 \\ Accepted: 27 February 2017 \\ Published: 21 March 2017 \\ Associate Editor: T. P. Yoon \\ (C) 2017 Devi and Das; licensee Beilstein-Institut. \\ License and terms: see end of document.
}

\begin{abstract}
While the exploitation of the Sharpless asymmetric dihydroxylation as the source of chirality in the synthesis of acyclic molecules and saturated heterocycles has been tremendous, its synthetic utility toward chiral benzo-annulated heterocycles is relatively limited. Thus, in the search for wider applications of Sharpless asymmetric dihydroxylation-derived diols for the synthesis of benzo-annulated heterocycles, we report herein our studies in the asymmetric synthesis of $(R)-1-((R)-6$-fluorochroman-2-yl)ethane1,2-diol, $(R)$-1-((S)-6-fluorochroman-2-yl)ethane-1,2-diol and (S)-6-fluoro-2-((R)-oxiran-2-yl)chroman, which have been used as late-stage intermediates for the asymmetric synthesis of the antihypertensive drug $(S, R, R, R)$-nebivolol. Noteworthy is that a large number of racemic and asymmetric syntheses of nebivolol and their intermediates have been described in the literature, however, the Sharpless asymmetric dihydroxylation has never been employed as the sole source of chirality for this purpose.
\end{abstract}

\section{Findings}

Chiral chromans are prevalent components of a large number of natural products, natural product-like molecules and pharmaceutical drugs, possessing diverse biological activities [1]. In view of their wide spectrum of biological profiles, chiral chromans have become attractive synthetic targets in academia and pharmaceutical industry [1]. Nebivolol (1, Figure 1) is a chroman-based antihypertensive drug that was first reported in the racemic form [2,3]. Chiral HPLC was subsequently employed to access various stereoisomers of $\mathbf{1}$ in enantiomerically pure form [4,5]. Out of the ten possible stereoisomers of $\mathbf{1}$, $(S, R, R, R)$-nebivolol or (+)-nebivolol (1a, Figure 1) was found to

be a potent $\beta_{1}$-adrenergic receptor blocker [2,3]. On the other hand, the corresponding enantiomeric form, $(R, S, S, S)$-nebivolol or (-)-nebivolol (1b, Figure 1) was found to be devoid of $\beta_{1}$-antagonist activity, but it showed a significant synergistic effect on the antihypertensive proficiency of the $(S, R, R, R)$ isomer [6-9].

A number of syntheses of nebivolol and its intermediates have been described in the literature [10-19]. Most of these have demonstrated that the synthesis of 1 a could be achieved using the 2-substituted chroman derivatives $(R)-1-((R)-6$-fluo- 
<smiles>OC(CNCC(O)C1CCc2cc(F)ccc2O1)C1CCc2cc(F)ccc2O1</smiles>

nebivolol 1<smiles>OC(CNCC(O)C1CCc2cc(F)ccc2O1)C1CCc2cc(F)ccc2O1</smiles>

$(S, R, R, R)$-nebivolol 1a<smiles>OC(CNCC(O)C1CCc2cc(I)ccc2O1)C1CCc2cc(F)ccc2O1</smiles>

$(R, S, S, S)$-nebivolol $\mathbf{1 b}$

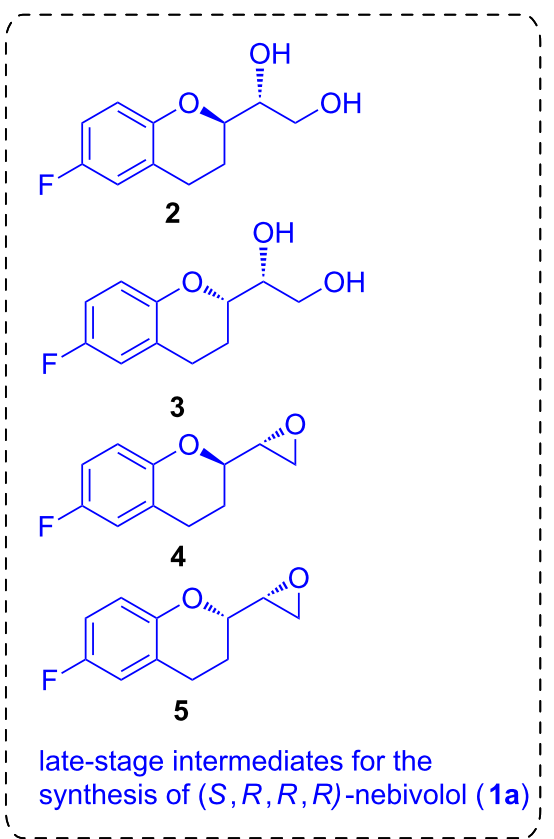

Figure 1: The chroman-based antihypertensive drug nebivolol, its biologically active stereoisomers and late-stage intermediates for its synthesis

rochroman-2-yl)ethane-1,2-diol (2) and $(R)$-1-((S)-6-fluorochroman-2-yl)ethane-1,2-diol (3) or the corresponding chroman epoxides $\mathbf{4}$ and $\mathbf{5}$ as late-stage intermediates. Although the consensus synthetic strategy for $\mathbf{1 a}$ involves the convergent assembly of chroman-based key subunits, the question of how best to access them remains open. The intramolecular ring-opening of enantiomerically pure epoxides by the phenolic hydroxy group is one of the most popular methods to construct 3 (Scheme 1, method 1). For this purpose, the necessary epoxide 6 could be obtained from the parent $E$-allylic alcohol through Sharpless asymmetric epoxidation (SAE) [11]. However, the corresponding parent $Z$-allylic alcohol appears to be not suitable to provide 7 under SAE conditions [20]. This has eliminated the possibility of obtaining 2 via intramolecular epoxide ring-opening of 7 (Scheme 1, method 2). Consequently, an alternative pathway involving the Mitsunobu inversion of 9<smiles>CC(C)(C)OC1CCc2cc(F)ccc2O1</smiles><smiles>OCC1OC1CCc1cc(F)ccc1O</smiles>
intramolecular epoxide ring opening<smiles>OC[C@@H](O)[C@H]1CCc2cc(F)ccc2O1</smiles>

7 (unaccessible by SAE) Mitsunobu $\uparrow$ inversion<smiles>COC1OC1CCc1cc(F)ccc1O</smiles><smiles>OC[C@@H](O)[C@H]1CCc2cc(F)ccc2O1</smiles> 
(obtained by intramolecular epoxide ring-opening of $\mathbf{8}$ which is the enantiomer of 6) has been followed to obtain 2 (Scheme 1, method 3) whereupon the overall yield of the reaction sequence diminished [11].

On the other hand, the Sharpless asymmetric dihydroxylation (SAD) has been a workhorse as a synthetic tool for accessing enantiopure vicinal diols [21]. The extensive work in this field has resulted in the discovery of a number of cinchona alkaloidderived ligands which allow the dihydroxylation of alkenes of almost all substitution patterns with high enantioselectivity. Noteworthy is that the SAD is not limited to only $E$-allylic alcohols in its choice of substrates as is the SAE process. Moreover, the SAD is much more superior in terms of operational simplicity as $\mathrm{SAE}$, it can be run at $0{ }^{\circ} \mathrm{C}$ in water as a co-solvent and under an atmosphere open to air.

The application of SAD-derived vicinal diols in the synthesis of acyclic molecules and saturated heterocycles has been astonishing. However, their utilities in the synthesis of chiral benzoannulated heterocycles are relatively limited [22-26]. In this paper, we describe our efforts toward the synthesis of 2, 3 and 5 using different cyclization strategies. To the best of our knowledge, nebivolol or its intermediates have never been synthesized using Sharpless asymmetric dihydroxylation as the sole source of chirality [27].
For the synthesis of chroman derivative 2, first a base-mediated intramolecular $\mathrm{S}_{\mathrm{N}} \mathrm{Ar}$ reaction was envisioned for the aryl $\mathrm{C}-\mathrm{O}$ bond formation under transition-metal-free conditions [28-30]. The additional benefit of this strategy would be the non-requirement of any protecting group to construct the chroman ring. To test this seemingly straightforward approach, we initially attempted to synthesize $( \pm)-2$ utilizing the cyclization of $( \pm)$ triol 14 (Scheme 2) as the key step.

Thus, commercially available 2,5-difluorobenzaldehyde (10) was treated with the Wittig reagent $\mathrm{Ph}_{3} \mathrm{P}=\mathrm{CHCO}_{2} \mathrm{Et}$ and the resulting unsaturated ester was then hydrogenated with $\mathrm{Pd}-\mathrm{C}$ and $\mathrm{H}_{2}$ at room temperature to obtain compound $\mathbf{1 1}$ in $91 \%$ yield over two steps (Scheme 2$)$. DIBAL-H (1.1 equiv, $-78{ }^{\circ} \mathrm{C}$ ) reduction of the ester group of $\mathbf{1 1}$ followed by Wittig olefination of the resulting crude aldehyde with $\mathrm{Ph}_{3} \mathrm{P}=\mathrm{CHCO}_{2}$ Et provided $(E)$ - $\alpha, \beta$-unsaturated ester 12 ( $80 \%$ over two steps). A further DIBAL-H $\left(2.5\right.$ equiv, $\left.0{ }^{\circ} \mathrm{C}\right)$ reduction of $\mathbf{1 2}$ delivered (E)-allylic alcohol 13 (90\%) which was then dihydroxylated under Upjohn conditions to obtain triol $( \pm)$-14 (92\%). With access to $( \pm)-\mathbf{1 4}$ we were in a position to investigate the key cyclization involving an intramolecular $\mathrm{S}_{\mathrm{N}} \mathrm{Ar}$ to deliver 2 . Unfortunately, all attempts of cyclizing $( \pm)-\mathbf{1 4}$ to obtain chroman derivative $( \pm)$-2 under various $\mathrm{S}_{\mathrm{N}} \mathrm{Ar}$ reaction conditions were not successful. Treatment of $( \pm)-\mathbf{1 4}$ with $\mathrm{KO} t-\mathrm{Bu} /$ THF $\left(65^{\circ} \mathrm{C}\right), \mathrm{NaH} / \mathrm{DMF}\left(80^{\circ} \mathrm{C}\right), \mathrm{NaH} / \mathrm{DMSO}\left(100^{\circ} \mathrm{C}\right)$ and

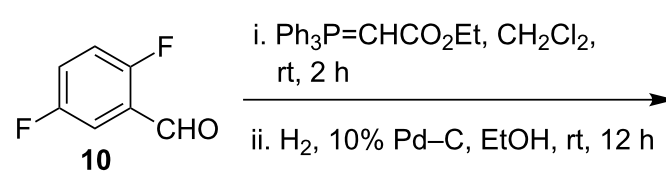

(91\% over two steps)<smiles>CCOC(=O)CCc1cc(F)ccc1F</smiles>

DIBAL-H (2.5 equiv)

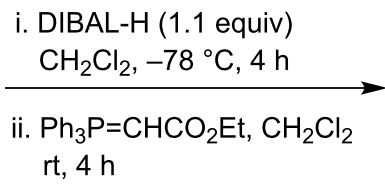

( $80 \%$ over two steps)<smiles>O=C(/C=C/CCc1cc(F)ccc1F)OF</smiles>
$\mathrm{CH}_{2} \mathrm{Cl}_{2}, 0^{\circ} \mathrm{C}, 2 \mathrm{~h}$

$(90 \%)$<smiles>OC/C=C/CCc1cc(F)ccc1F</smiles>

13

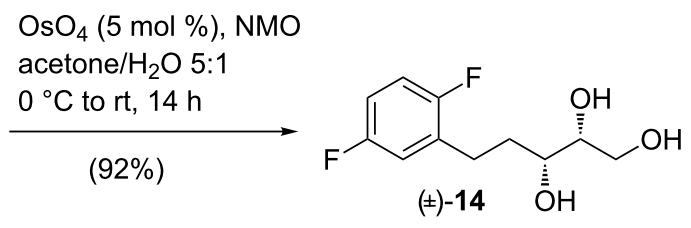

$( \pm)-14 \quad$ ÖH

different conditions as mentioned in the text<smiles>OC[C@@H](O)[C@H]1CCc2cc(F)ccc2O1</smiles>

$( \pm)-2$ (not formed) 
$\mathrm{KO} t$-Bu/toluene $\left(110^{\circ} \mathrm{C}\right)$ did not lead to any conversion. However, more forcing conditions such as NaH/NMP $\left(130^{\circ} \mathrm{C}\right)$ resulted in a to partial decomposition of the starting material. These results indicated that an intramolecular $\mathrm{S}_{\mathrm{N}} \mathrm{Ar}$ reaction of triol $( \pm)$-14 to form $( \pm)$-2 is not feasible. Thus, the presence of an activating substituent (e.g., a nitro group) at the C-5 position of the benzene ring might be helpful in synthesizing molecules similar to $2[31,32]$.

The failure to achieve an intramolecular cyclization of the diol via an $\mathrm{S}_{\mathrm{N}} \mathrm{Ar}$ reaction caused us to investigate other cyclization approaches towards these chroman derivatives. In 2005, Borhan and co-workers described the construction of tetrahydrofuran and tetrahydropyran structures from 1,2,n-triols via an elegant cyclization involving Lewis acid-mediated cyclization of in situ generated cyclic orthoesters [33]. We speculated that a similar reaction on an appropriately positioned diol with a tethered $o$-hydroxyphenyl group might produce 2-substituted chroman derivatives via a 6-exo-tet cyclization (Scheme 3).

To substantiate this hitherto unexplored approach in the context of synthesizing $(+)$-nebivolol intermediates, we first needed to synthesize the syn-dihydroxy esters 19 and 20 (Scheme 4). Toward that objective, 2-allyl-4-fluorophenol (15) was benzylated with $\mathrm{BnCl}$ and anhydrous $\mathrm{K}_{2} \mathrm{CO}_{3}$ in the presence of $\mathrm{KI}$ in acetone under reflux conditions to obtain benzyl ether $\mathbf{1 6}$ (Scheme 4). The subsequent hydroboration of the allyl group in 16 with 9-BBN and the oxidation of the resulting organoborane with $\mathrm{NaOH}$ and $\mathrm{H}_{2} \mathrm{O}_{2}$ furnished alcohol 17 in $96 \%$ yield. A one-pot PCC oxidation-Wittig olefination (with<smiles>[R][R]c1ccc(O)c(CC[C@H](O)[C@H](O)C(OCC)OCC)c1</smiles>

Scheme 3: Speculation on the synthesis of a 2-substituted chroman derivative based on Borhan's approach.

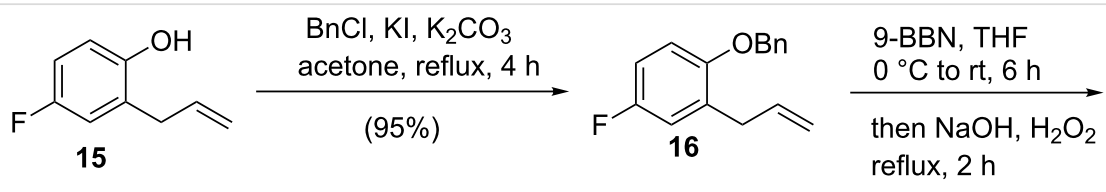

(96\% over two steps)<smiles>OCCCc1cc(F)ccc1OCc1ccccc1</smiles>

PCC, celite, $\mathrm{CH}_{2} \mathrm{Cl}_{2}$<smiles>CCOC(=O)/C=C/CCc1cc(F)ccc1OCc1ccccc1</smiles>

$\mathrm{CH}_{2} \mathrm{Cl}_{2}, \mathrm{rt}, 4 \mathrm{~h}$

(85\% over two steps)<smiles>CCOC(=O)[C@H](O)[C@@H](O)CCc1cc(F)ccc1OCc1ccccc1</smiles>

$\mathrm{AD}-\mathrm{mix}-\alpha, t-\mathrm{BuOH} / \mathrm{H}_{2} \mathrm{O}$

$0{ }^{\circ} \mathrm{C}, 24 \mathrm{~h}$

(89\%)<smiles>CCOC(=O)[C@H](O)[C@@H](O)CCc1cc(F)ccc1OCc1ccccc1</smiles>

$\mathrm{AD}-\mathrm{mix}-\beta, t-\mathrm{BuOH} / \mathrm{H}_{2} \mathrm{O}$ $0{ }^{\circ} \mathrm{C}, 24 \mathrm{~h}$

$(87 \%)$ 
$\mathrm{Ph}_{3} \mathrm{P}=\mathrm{CHCO}_{2} \mathrm{Et}$ ) of $\mathbf{1 7}$ provided $(E)-\alpha, \beta$-unsaturated ester $\mathbf{1 8}$ in $85 \%$ yield over 2 steps. Compound $\mathbf{1 8}$ was then subjected to a Sharpless asymmetric dihydroxylation with AD-mix- $\alpha$ in $t$-BuOH$/ \mathrm{H}_{2} \mathrm{O}(1: 1)$ at $0{ }^{\circ} \mathrm{C}$ for $24 \mathrm{~h}$ furnishing syn-2,3-dihydroxy ester 19 in a high yield of $92 \%$. For the synthesis of syn-2,3-dihydroxy ester 20, AD-mix- $\beta$ was employed.

Debenzylation of diol 20 with $\mathrm{Pd}-\mathrm{C}$ and $\mathrm{H}_{2}$ at room temperature produced compound $\mathbf{2 1}$ having a tethered $o$-hydroxyphenyl group (Scheme 5). Next, compound 21 was exposed to Borhan's reaction conditions with the hope to obtain $\mathbf{2 2}$. To our dismay, however, the reaction furnished the hydrolyzed product $\mathbf{2 3}$ instead of cyclized product 22. It is important to mention that strict anhydrous conditions were maintained for this transformation in order to prevent the nucleophilic attack of $\mathrm{H}_{2} \mathrm{O}$ leading to the formation of $\mathbf{2 3}$. However, the formation of $\mathbf{2 3}$ instead of 22 clearly indicates that the in situ generated cyclic orthoester, after getting activated by Lewis acid, did not experience a nucleophilic attack of the phenolic hydroxy group; instead it reacted with water during the work-up process. This different outcome of this reaction compared to Borhan's results might be attributed to the lower nucleophilicity of phenols compared to alcohols.

Previously, Panda and co-worker converted succesfully a syn2,3-dihydroxy ester into a 2-substituted chroman derivative [23]. The above-described unfortunate failures eventually forced us to turn our attention to utilize this methodology for the synthesis of 2-substituted chroman derivatives. Thus, diols 19 and 20 were subjected to a monotosylation reaction [34] to obtain the $\beta$-hydroxy- $\alpha$-tosyloxy esters $\mathbf{2 4}$ and $\mathbf{2 5}$, respectively (Scheme 6).

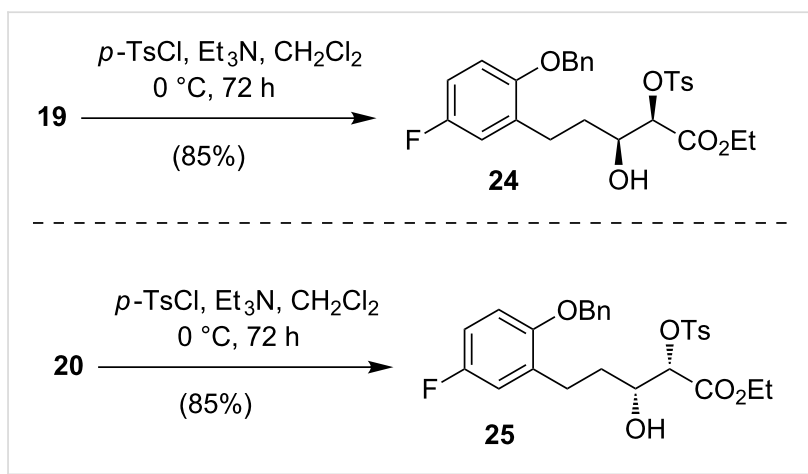

Scheme 6: Synthesis of $\beta$-hydroxy- $\alpha$-tosyloxy esters $\mathbf{2 4}$ and 25.

Panda and co-worker applied a three-step reaction sequence involving epoxidation/debenzylation/epoxide ring-opening to convert the $\beta$-hydroxy- $\alpha$-tosyloxy ester into the corresponding 2 -substituted chroman derivative. However, it has been reviewed that not only benzylic epoxides but also non-benzylic epoxides are sensitive to the standard hydrogenation/debenzylation conditions [35]. Whereas benzylic epoxides are highly sensitive to hydrogenation conditions, non-benzylic epoxides, depending on the reaction conditions, may produce traces to significant amounts of side-products via hydrogenolysis. Thus, we decided to modify Panda's synthetic route to significantly increase the overall yield. We hypothesized that this problem might be circumvented by performing the debenzylation reaction prior to the epoxide-ring formation. Further we speculated

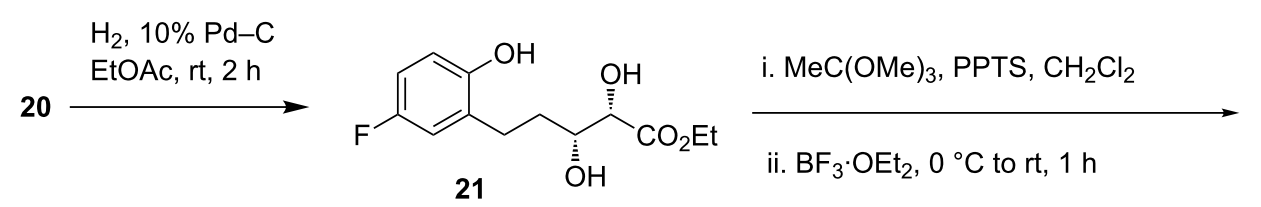

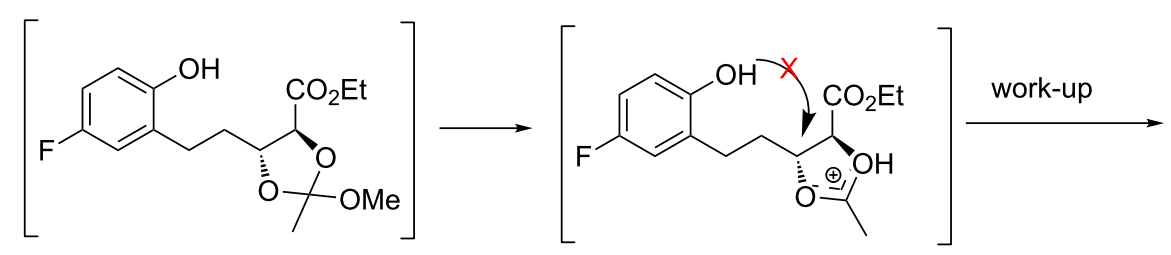<smiles>CCOC(=O)[C@H](OC(C)=O)[C@H]1CCc2cc(F)ccc2O1</smiles><smiles>CCOC(=O)[C@H](O)[C@@H](CCc1cc(F)ccc1O)OC(C)=O</smiles>

23 (obsereved product, yield: $40 \%$ over two steps) 
that compound 26, in the presence of a base, might undergo a simultaneous epoxidation-intramolecular epoxide-ring opening to produce 27 (Scheme 7) as the corresponding benzoxepin ring formation via intramolecular displacement of -OTs group by $\mathrm{ArO}^{-}$is unresponsive [23].

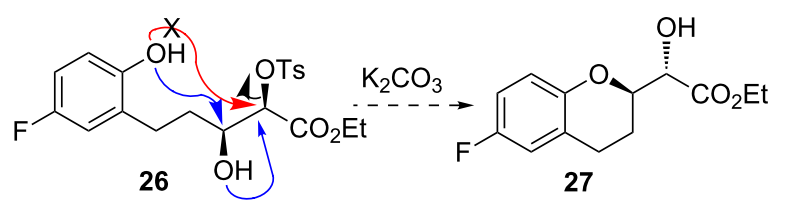

Scheme 7: Speculation of simultaneous epoxidation/epoxide-ring opening.

To test this hypothesis, first compound $\mathbf{2 4}$ was subjected to the debenzylation reaction with $10 \% \mathrm{Pd}-\mathrm{C}$ in $\mathrm{EtOH}$ under an $\mathrm{H}_{2}$ atmosphere (Scheme 8) at room temperature. After completion of the debenzylation process, $\mathrm{K}_{2} \mathrm{CO}_{3}$ was added to the reaction mixture in the same reaction vessel. The reaction mixture, after being run for additional $6 \mathrm{~h}$, provided compound 27 in $70 \%$ yield which is significantly higher than the literature yield (53\%) for the similar transformation [23]. The similar strategy was applied in converting $\mathbf{2 5}$ into chroman derivative $\mathbf{2 8}$. Next, $\mathrm{LiAlH}_{4}$ reduction of $\mathbf{2 7}$ and $\mathbf{2 8}$ provided $\mathbf{2}$ and $\mathbf{2 9}$, respectively, in $93 \%$ yield. It is to be mention that the NMR spectra and spe- cific rotations of $\mathbf{2}$ and $\mathbf{2 9}$ matched with those reported in the literature $[11,14,15]$. For the synthesis of compound 3, stereoisomer 29 was subjected to classical two-step Mitsunobu inversion protocol which was successful but poor yielding (Scheme 9).

Not surprised by the poor yield of this transformation, we focused on the conversion of $\mathbf{2 8}$ into $\mathbf{5}$ which has also been used as a late-stage nebivolol intermediate ( $\mathbf{5}$ is a more advanced intermediate compared to $\mathbf{3}$ ). Thus, the tosylation of compound 28 followed by $\mathrm{LiBH}_{4}$ reduction of the resulting tosylate and subsequent epoxidation of the obtained tosyloxy alcohol with anhydrous $\mathrm{K}_{2} \mathrm{CO}_{3}$ in absolute ethanol (Scheme 10) provided compound $\mathbf{5}$.

$28 \stackrel{\text { ii. } \mathrm{LiBH}_{4}, \mathrm{THF}, 0{ }^{\circ} \mathrm{C} \text { to rt, } 8 \mathrm{~h}}{\longrightarrow}$

i. $\mathrm{TsCl}, \mathrm{Et}_{3} \mathrm{~N}, \mathrm{CH}_{2} \mathrm{Cl}_{2}, \mathrm{rt}, 12 \mathrm{~h}$

iii. $\mathrm{K}_{2} \mathrm{CO}_{3}$, ethanol, $\mathrm{rt}, 10 \mathrm{~h}$

(62\% over three steps)

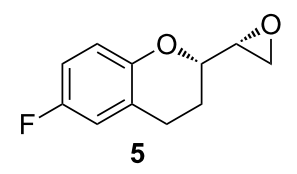

Scheme 10: Synthesis of chroman epoxide 5.

The NMR spectra and specific rotations of $\mathbf{5}$ also matched those reported in the literature [17-19,36].

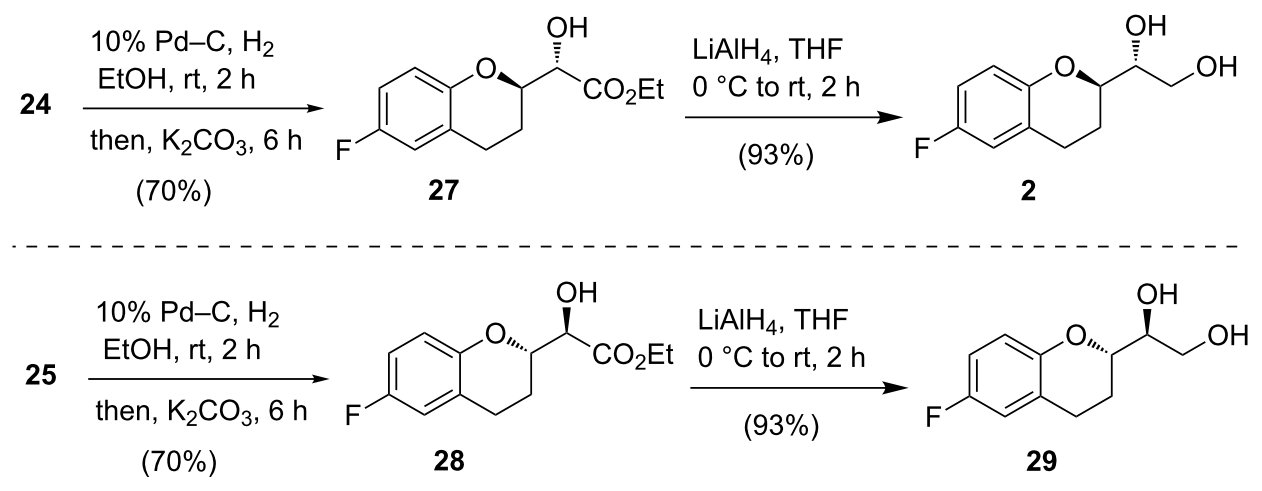

Scheme 8: Synthesis of chroman diols 2 and 29, respectively.

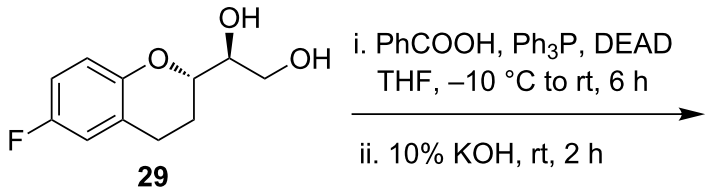

(38\% over two steps)<smiles>OC[C@@H](O)C1CCc2cc(F)ccc2O1</smiles>

3 


\section{Conclusion}

In summary, in the context of exploiting Sharpless asymmetric dihydroxylation-derived vicinal diols in the synthesis of $(R)-1$ $((R)$-6-fluorochroman-2-yl)ethane-1,2-diol, $(R)$-1- $((S)$-6-fluorochroman-2-yl)ethane-1,2-diol and $(S)$-6-fluoro-2-((R)-oxiran2 -yl)chroman, which have previously utilized as late-stage intermediates for the synthesis of $(S, R, R, R)$-nebivolol, we have extensively studied different cyclization strategies. The construction of 2 -substituted chroman derivatives using phenolic hydroxy-mediated intramolecular ring opening of syn2,3-diol ester-derived cyclic orthoester or intramolecular $\mathrm{S}_{\mathrm{N}} \mathrm{Ar}$ reaction of a triol containing a tethered 2,5-difluorophenyl substituent were not successful. However, the exposure of $\beta$-hydroxy- $\alpha$-tosyloxy esters to a one-pot, three-step process (debenzylation-epoxidation-intramolecular epoxide ring opening) enabled us to acheive the target molecules. To the best of our knowledge, this is the first use of the Sharpless asymmetric dihydroxylation as the sole source of chirality for the synthesis of nebivolol intermediates.

\section{Supporting Information}

\section{Supporting Information File 1}

Experimental procedures, characterization data and copies of ${ }^{1} \mathrm{H}$ and ${ }^{13} \mathrm{C}$ NMR spectra for final compounds are available.

[http://www.beilstein-journals.org/bjoc/content/ supplementary/1860-5397-13-56-S1.pdf]

\section{Acknowledgements}

We acknowledge the financial support provided by the Department of Science and Technology [(DST), SB/FT/CS-073/2013], and the University Grant Commission [F30-33/2014(BSR)], New Delhi, India.

\section{References}

1. Shen, H. C. Tetrahedron 2009, 65, 3931-3952. doi:10.1016/j.tet.2009.02.002

2. De Crée, J.; Geukens, H.; Leempoels, J.; Verhaegen, H. Drug Dev. Res. 1986, 8, 109-117. doi:10.1002/ddr.430080114

3. Van Lommen, G. R. E.; De Bruyn, M. F. L.; Schroven, M. F. J. Derivatives of 2,2'-iminobisethanol. U.S. Patent US4,654,362, March 31, 1987.

4. Pauwels, P. J.; Gommeren, W.; van Lommen, G.; Janssen, P. A. J.; Leysen, J. E. Mol. Pharmacol. 1988, 34, 843-851.

5. Van Lommen, G.; De Bruyn, M.; Schroven, M. J. Pharm. Belg. 1990, 45, 355-360.

6. Midol-Monet, M.; Davy, M.; Heimburger, M.; Beslot, F.; Cohen, Y. J. Pharm. Pharmacol. 1991, 43, 504-509. doi:10.1111/j.2042-7158.1991.tb03523.x
7. Van de Water, A.; Xhonneux, R. S.; Reneman, R. S.; Janssen, P. A. J. Eur. J. Pharmacol. 1988, 156, 95-103. doi:10.1016/0014-2999(88)90151-3

8. Xhonneux, R.; Wouters, L.; Reneman, R. S.; Janssen, P. A. J. Eur. J. Pharmacol. 1990, 181, 261-265. doi:10.1016/0014-2999(90)90087-M

9. Bowden, C. R.; Marchione, C. S. J. Pharmacol. Exp. Ther. 1989, 251, 599-605.

10. Johannes, C. W.; Visser, M. S.; Weatherhead, G. S.; Hoveyda, A. H. J. Am. Chem. Soc. 1998, 120, 8340-8347. doi:10.1021/ja981378o

11. Chandrasekhar, S.; Reddy, M. V. Tetrahedron 2000, 56, 6339-6344. doi:10.1016/S0040-4020(00)00572-X

12. Yang, Y. X.; Wang, N. X.; Xing, Y. L.; Wang, W. W.; Zhao, J.; Wang, G. X.; Tang, S. Chin. Chem. Lett. 2005, 16, 1577-1580.

13. Yu, A.-G.; Wang, N.-X.; Xing, Y.-L.; Zhang, J.-P.; Yang, Y.-X.; Wang, W.-W.; Sheng, R.-I. Synlett 2005, 1465-1467. doi:10.1055/s-2005-868508

14. Bai, Y.; Chen, X. J. Chem. Res. 2006, 807-808. doi:10.3184/030823406780199802

15. Wang, N.-X.; Yu, A.-G.; Wang, G.-X.; Zhang, X.-H.; Li, Q.-S.; Li, Z. Synthesis 2007, 1154-1158. doi:10.1055/s-2007-965993

16. Carreño, M. C.; Hernández-Torres, G.; Urbano, A.; Colobert, F. Eur. J. Org. Chem. 2008, 2035-2038. doi:10.1002/ejoc.200800201

17. Bartoli, S.; Cipollone, A.; Fattori, D. Process for the preparation of nebivolol. PCT Patent Application WO2011/098474 A1, Aug 18, 2011.

18. Mauro, S.; Fattori, D.; D'Andrea, P.; Cipollone, A. Process for the preparation of nebivolol. PCT Patent Application WO2012/095707 A1, July 19, 2012.

19. Jas, G.; Freifeld, I.; Kesseler, K. Method for producing nebivolol. PCT Patent Application WO2011/091968 A1, Aug 4, 2011.

20. Khandavalli, P. C.; Spiess, O.; Boehm, O. M.; Freifeld, I.; Kesseler, K.; Jas, G.; Schinzer, D. J. Org. Chem. 2015, 80, 3965-3973. doi:10.1021/acs.joc.5b00263

21. Kolb, H. C.; VanNieuwenhze, M. S.; Sharpless, K. B. Chem. Rev. 1994, 94, 2483-2547. doi:10.1021/cr00032a009

22. Manabe, Y.; Kanematsu, M.; Osaka, M.; Yoshida, M.; Shishido, K. Heterocycles 2014, 88, 441-452. doi:10.3987/COM-13-S(S)50

23. Das, S. K.; Panda, G. Tetrahedron 2008, 64, 4162-4173. doi:10.1016/j.tet.2008.03.001

24. Das, S. K.; Dinda, S. K.; Panda, G. Eur. J. Org. Chem. 2009, 204-207. doi:10.1002/ejoc.200800661

25. Khadem, S.; Joseph, R.; Rastegar, M.; Leek, D. M.; Oudatchin, K. A.; Arya, P. J. Comb. Chem. 2004, 6, 724-734. doi:10.1021/cc049941o

26. Kishuku, H.; Yoshimura, T.; Kakehashi, T.; Shindo, M.; Shishido, K. Heterocycles 2003, 61, 125-131. doi:10.3987/COM-03-S4

27. Previously, Sharpless asymmetric dihydroxylation was used to create one of the two chiral centers of each chroman unit of nebivolol. See reference [16] above.

28. Devi, R.; Gogoi, D.; Bora, P.; Das, S. K. Tetrahedron 2016, 72 , 4878-4888. doi:10.1016/j.tet.2016.06.059 See for the construction of the aryl $\mathrm{C}-\mathrm{O}$ bond of benzo-fused oxo-heterocycles via intramolecular $S_{N} A r$ reaction between a hydroxy group and unactivated aryl fluoride; see also references $[29,30]$ below.

29. Singha, R.; Ahmed, A.; Nuree, Y.; Ghosh, M.; Ray, J. K. RSC Adv. 2015, 5, 50174-50177. doi:10.1039/C5RA07532G

30. Shi, G. Q.; Dropinski, J. F.; Zhang, Y.; Santini, C.; Sahoo, S. P.; Berger, J. P.; MacNaul, K. L.; Zhou, G.; Agrawal, A.; Alvaro, R.; Cai, T.-q.; Hernandez, M.; Wright, S. D.; Moller, D. E.; Heck, J. V.; Meinke, P. T. J. Med. Chem. 2005, 48, 5589-5599. doi:10.1021/jm050373g 
31. Zezula, J.; Singer, L.; Przybyl, A. K.; Hashimoto, A.; Dersch, C. M.; Rothman, R. B.; Deschamps, J.; Lee, Y. S.; Jacobson, A. E.; Rice, K. C. Org. Biomol. Chem. 2008, 6, 2868-2883. doi:10.1039/b803433h See for the construction of the aryl C-O bond of benzo-fused oxo-heterocycles via intramolecular $S_{N} A r$ reaction between a hydroxy group and activated aryl fluoride.

32. Kurimura, M.; Liu, H.; Sulima, A.; Hashimoto, A.; Przybyl, A. K.; Ohshima, E.; Kodato, S.; Deschamps, J. R.; Dersch, C. M.; Rothman, R. B.; Lee, Y. S.; Jacobson, A. E.; Rice, K. C. J. Med. Chem. 2008, 51, 7866-7881. doi:10.1021/jm800913d

33. Zheng, T.; Narayan, R. S.; Schomaker, J. M.; Borhan, B. J. Am. Chem. Soc. 2005, 127, 6946-6947. doi:10.1021/ja043002i

34. Fleming, P. R.; Sharpless, K. B. J. Org. Chem. 1991, 56, 2869-2875. doi:10.1021/jo00008a051

35. Thiery, E.; Le Bras, J.; Muzart, J. Eur. J. Org. Chem. 2009, 961-985. doi:10.1002/ejoc.200800739

36. Horiguchi, A.; Kuge, Y.; Mochida, K.-i. J. Mol. Catal. B: Enzym. 1997, 3, 285-292. doi:10.1016/S1381-1177(97)00013-1

\section{License and Terms}

This is an Open Access article under the terms of the Creative Commons Attribution License (http://creativecommons.org/licenses/by/4.0), which permits unrestricted use, distribution, and reproduction in any medium, provided the original work is properly cited.

The license is subject to the Beilstein Journal of Organic Chemistry terms and conditions:

(http://www.beilstein-journals.org/bjoc)

The definitive version of this article is the electronic one which can be found at: doi:10.3762/bjoc. 13.56 